\section{PENDAMPINGAN PEMBUATAN KUIS DENGAN APLIKASI QUIZIZZ BAGI GURU SEKOLAH DASAR DI DESA MADE LAMONGAN}

Ummu Khairiyah*, Silviana Nur Faizah, Awaliah Dea Lestari

Pendidikan Ibtidaiyah, Lamongan

Guru Madrasah Universitas Islam

\begin{abstract}
Abstrak
Kondisi Pandemi dengan adanya Covid-19 memaksa kegiatan pembelajaran berlangsung secara jarak jauh atau dilakukan secara online. Hal tersebut membuat pendidik harus siap menggunakan aplikasi-aplikasi pembelajaran guna menunjang pembelajaran secara jarak jauh. Tujuan kegiatan pengabdian masyarakat ini adalah untuk memberikan pengetahuan dan membekali pendidik sehingga terampil dalam menggunakan media pembelajaran berbasis online. Pengabdian masyarakat ini memfokuskan dalam penggunaan aplikasi atau platform "Quizizz" dalam pembuatan evaluasi pembelajaran berbentuk kuis interaktif. Metode pelaksanaan melalui pelatihan secara daring (online) dengan ceramah, diskusi, dan praktek penggunaan Quizizz. Subjek dari pelatihan ini adalah Guru Sekolah Dasar di Desa Made Kecamatan Lamongan Kabupaten Lamongan berjumlah 32 orang. Tujuan yang dicapai yaitu penggunaan aplikasi Quizizz dalam membuat evaluasi pembelajaran yang interaktif dan menyenangkan bagi peserta didik. Berdasarkan pelatihan yang telah dilakukan, diperoleh hasil bahwa para peserta terlihat sangat antusias dibuktikan dengan aktifnya para peserta dalam bertanya, berdiskusi, dan menjawab pertanyaan yang diberikan oleh pemateri. $87 \%$ peserta pelatihan mampu mengembangkan tes interaktif dengan aplikasi Quizizz dan 81 \% peserta mampu mengujicobakan aplikasi Quizizz kepada peserta didiknya. Pelatihan ini sangat bermanfaat dilakukan bagi guru guna memotivasi peserta didik dalam melakukan evaluasi pembelajaran supaya lebih menyenangkan.
\end{abstract}

Kata Kunci: Kuis Interaktif; Media Pembelajaran Online; Quizizz

\section{*Corresponding author}

Ummu Khairiyah

Email: ummukhairiyah@unisla.ac.id

\begin{abstract}
Pandemic conditions with Covid-19 forced learning activities to take place remotely or be carried out online. This makes educators ready to use learning applications to support distance learning. This community service activity aims to provide knowledge and equip educators so that they are skilled in using online-based learning media. This community service focuses on using the "Quizizz" application or platform in making learning evaluations in the form of interactive quizzes. The method of implementation is through online training with lectures, discussions, and practice using quizzes. These training subjects were 32 elementary school teachers in Made Village, Lamongan District, Lamongan Regency. The goal achieved is to use the Quizizz application in making interactive and fun learning evaluations for students. Based on the training that had been carried out, the results showed that the participants looked very enthusiastic, as evidenced by the participants' active participation in asking, discussing, and answering questions given by the presenters. $87 \%$ of training participants were able to develop interactive tests with the Quizizz application, and $81 \%$ of participants were able to try out the Quizizz application to their students. This training is very useful for teachers to motivate students in evaluating learning to make it more enjoyable.
\end{abstract}

Keywords: Interactive Quizzes; Online Learning Media; Quizizz

(c) 2021 Some rights reserved

\section{PENDAHULUAN}

Saat ini corona menjadi perbincangan yang hangat di belahan bumi manapun. Severe Acute Respiratory Syndrome Coronavirus 2 (SARS-COV-2) yang lebih dikenal dengan nama virus corona adalah jenis baru dari yang menyebabkan penyakit menular ke manusia. Hal tersebut membuat beberapa negara menetapkan kebijakan untuk melakukan lockdown dalam rangka memutus rantai penyebaran virus corona, sehingga semua kegiatan yang dilakukan diluar rumah harus dihentikan sampai pandemi ini mereda, termasuk kegiatan pendidikan. 
Seluruh kegiatan pembelajaran harus diadakan secara jarak jauh melalui pembelajaran daring. Terkait dengan dampak tersebut, para pendidik dan peserta didik dituntut untuk mampu dengan cepat beradaptasi dengan perubahan yang ada. Sistem pembelajaran yang semua berbasis tatap muka harus digantikan dengan sistem pembelajaran yang diintegrasikan melalui jaringan internet (pembelajaran online).

Pembelajaran online merupakan pembelajaran yang menghubungkan peserta didik dengan sumber belajar yang secara fisik terpisah namun dapat saling berinteraksi, berkomunikasi, dan berkolaborasi (Arizona et al., 2020). Pembelajaran online adalah jenis pembelajaran dimana cara penyampaian materi pembelajaran menggunakan media internet, jaringan internet atau media jaringan komputer lainnya (Hartley, 2001). Tidak hanya materi pembelajaran yang harus disampaikan secara online, namun kegiatan evaluasi pembelajaran juga harus dilakukan secara online, karena pada dasarnya evaluasi pembelajaran merupakan aktivitas mengetahui keberhasilan proses dan hasil belajar yang dihasilkan oleh peserta didik setelah peserta didik menempuh tahap-tahap pembelajaran (Nurzannah \& Setiawan, 2020). Evaluasi pembelajaran selain untuk mengetahui ketercapaian indikator pembelajaran oleh peserta didik, juga dapat dijadikan informasi dalam mengetahui prestasi peserta didik dalam kelompoknya. Sependapat dengan Safi'i (2018) yang menyatakan bahwa tingkat pemahaman dan kemampuan siswa terhadap materi yang telah dipelajari dapat diketahui melalui evaluasi atau penilaian. Selain itu, penilaian hasil belajar juga bertujuan mengukur keberhasilan guru dalam melaksanakan kegiatan pembelajaran sekaligus mengukur pemahaman siswa terhadap materi yang telah disampaikan dalam pembelajaran (labal et al., 2018). Kualitas pembelajaran dapat dilihat dari hasil penilaiannya sehingga guru harus mampu mengembangkan alat evaluasi pembelajaran dengan berbagai media yang tepat (Mardapi, 2012).

Sebelum adanya pandemic covid-19, evaluasi pembelajaran umumnya dengan menggunakan lembar soal dalam bentuk cetak yang dikerjakan oleh siswa dan diawasi oleh guru. Akan tetapi, pada masa pandemic covid-19 ini tidak memungkinkan menggunakan lembar evaluasi dalam bentuk cetak. Lembar evaluasi menggunakan kertas dalam pelaksanaannya dirasa kurang efektif (Pratiwi, 2017). Rolisca \& Achadiyah (2014) dalam penelitiannya juga menjelaskan bahwa siswa cenderung bosan, tidak serius dalam mengerjakan soal, dan takut sehingga siswa kurang termotivasi dan kurang tertarik. Kegiatan evaluasi atau tes seharusnya dijadikan kebutuhan oleh peserta didik, karena dengan tes, peserta didik akan mengetahui tentang keberhasilan setelah mengikuti kegiatan pembelajaran (Suryana \& Irawantoro, 2016). Alat evaluasi yang baik adalah alat evaluasi yang memenuhi syarat-syarat atau kaidah-kaidah tertentu dan dapat memberikan data yang akurat sesuai dengan fungsinya (Arifin, 2016).

Media evaluasi pembelajaran online merupakan sarana atau alat evaluasi yang tepat yang bisa digunakan secara daring. Aplikasi-aplikasi berbasis website menyediakan sarana yang mudah dalam proses evaluasi pembelajaran (Fuady, 2017). Salah satu contoh aplikasi yang dapat digunakan untuk melakukan penilaian adalah Quizizz. Quizizz merupakan sebuah web tool untuk membuat tes interaktif yang digunakan untuk melakukan penilaian formatif (Suyasa et al., 2019). Aplikasi Quizizz merupakan platform teknologi pembelajaran yang mengkombinasikan evaluasi pembelajaran melalui permainan interaktif yang dilengkapi dengan sistem pengawasan bagi aktivitas peserta didik. Aplikasi Quizizz juga mampu membantu guru dalam membuat evaluasi pembelajaran menjadi menarik, interaktif, dan dapat dikaitkan dengan aplikasi google classroom sehingga memudahkan untuk memantau hasil belajar peserta didik. Demikian halnya dengan pendapat Purba (2019) bahwa Quizizz merupakan aplikasi berbasis game yang membawa aktivitas di kelas latihan interaktif dan menyenangkan.

Quizizz sekarang bisa diakses di playstore bagi pengguna android sehingga dalam penggunaanya lebih praktis. Ada dua pilihan untuk membuat soal dengan aplikasi Quizizz. Pertama dengan membuat soal dari awal yakni dengan menu create a new quiz, dan yang kedua dengan menggunakan dan memodifikasi kuis yang telah ada di library Quizizz dengan menggunakan menu find a quiz. Selain itu pengguna juga bisa mengcopy dari soal-soal yang telah ada dengan menu teleport.

Kelebihan dari aplikasi Quizizz tidak hanya menyediakan guru untuk membuat soal pilihan ganda (multiple choice) melainkan ada tipe soal kotak centang (checkbox), isi bagian yang kosong (Fill-in-the blank), pemilihan (poll), dan terbukaberakhir (open ended). Selain itu Quizizz juga memberikan rekapan secara statistik tentang kinerja peserta didik. Kita bisa melacak berapa banyak peserta didik menjawab soal dengan benar, menjawab dengan salah, dan banyak lagi. Peserta didik juga bisa melihat hasil kinerjanya secara langsung dan dapat mengetahui peringkat yang diperoleh ketika mengerjakan soal di Quizizz. Hal tersebut dapat memotivasi peserta didik untuk bersaing secara kompetitif melalui fitur "Play Live" atau mengerjakan soal secara bersama-sama dengan peserta didik yang lain dalam waktu yang bersamaan. Selain fitur play live juga tersedia fitur 
assign Hw dimana memungkinkan peserta didik untuk mengerjakan soal yang telah dibuat oleh guru dengan menetapkan tes sebagai pekerjaan rumah yang dibatasi waktu pengerjaannya. Aplikasi Quizizz merupakan aplikasi yang hemat dalam penggunaan data internet dan mudah digunakan oleh guru serta siswa (Sari \& Rini, 2020).

Kelebihan lain dari aplikasi Quizizz bagi peserta didik yakni setiap peserta didik menjawab pertanyaan dengan benar, maka akan muncul skor yang didapat dalam satu soal dan juga mendapat peringkat dalam menjawab soal tersebut, apabila peserta didik menjawab pertanyaan salah, maka jawaban yang benar akan muncul sehingga peserta didik dapat melakukan review atas jawaban yang telah dipilih sebelumnya. Selain itu setiap peserta didik akan mendapatkan pertanyaan yang berbeda dengan peserta didik lain dikarenakan soal yang muncul akan diacak, sehingga meminimalisir kemungkinan peserta didik untuk saling tukar jawaban atau mencontek, batas waktu pengerjaan setiap soal juga bisa disesuaikan dengan tingkat kesukaran dari masing-masing pertanyaan. Hal ini membuat media Quizizz menjadi media e-learning yang sangat efektif untuk mengevaluasi dan memberikan hasil secara cepat kepada guru sehingga guru bisa mengambil tindakan sesegera mungkin kepada siswa (Yan mei et al., 2018).

Sayangnya dengan berbagai kemudahan yang dimiliki oleh Quizizz tidak menjadikan Quizizz dikenal dan dimanfaatkan oleh beberapa Guru termasuk guru sekolah dasar di Desa Made kecamatan lamongan, kabupaten lamongan. Para guru selama pembelajaran jarak jauh, masih mengandalkan cara konvensional dalam melakukan kegiatan evaluasi pembelajaran yakni dengan cara peserta didik mengirimkan foto hasil pengerjaan Lembar Kegiatan Siswa dan dikirim melalui grup Whatsapp. Sistem ini membuat peserta didik tampak kurang antusias saat pelaksanaan evaluasi berlangsung dengan terlihat semakin berkurangnya jumlah peserta didik yang mengumpulkan hasil evaluasi dikarenakan evaluasi cenderung monoton. Selama masa pandemi, tidak adanya interaksi yang baik antara guru dan peserta didik. Guru tidak memberikan umpan balik kepada peserta didik setelah mengerjakan evaluasi sehingga peserta didik tidak tahu apakah yang dikerjakan sudah benar atau salah, dan guru mengalami kesulitan dalam penggunaan aplikasi berbasis kuis.

Kegiatan pengabdian masyarakat ini bertujuan untuk memberikan pelatihan kepada guru dalam mengembangkan tes evaluasi pembelajaran menggunakan aplikasi Quizizz serta memberikan pelatihan penggunaan aplikasi Quizizz sebagai alat evaluasi pembelajaran.

\section{METODE PELAKSANAAN}

Pelaksanaan kegiatan ini dilaksanakan selama empat hari yakni pada tanggal 5 - 8 Agustus 2020 bersama Guru sekolah dasar di Desa Made Kecamatan Lamongan Kabupaten Lamongan Provinsi Jawa Timur berjumlah 32 Guru dari 3 Sekolah dasar yang ada di desa Made. Dikarenakan kondisi pandemic covid-19, pelaksanaan pelatihan dilakukan secara online melalui Group WhatsApp, tim juga mempersiapkan materi tutorial secara streaming melalui Youtube.

\section{Tahap Perencanaan}

Tim melakukan survey ke lokasi untuk mengetahui kondisi dan permasalahan di wilayah sasaran. Survey dilakukan di 3 sekolah yang berada di Desa Made dengan mengumpulkan data dan informasi melalui observasi, dan menyebarkan kuisioner terkait proses pembelajaran selama era pandemic ini. Dengan peserta berjumlah 32 orang Guru, tim membuat Group WhatsApp sebagai sarana pelaksanaan pelatihan online. Bersamaan dengan itu, tim bekerja menyiapkan materi, jadwal kegiatan, platform yang akan digunakan dalam proses pelatihan, serta koneksi jaringan internet.

\section{Tahap Pelaksanaan}

Pada tahap pelaksanaan, tim bersama mitra melakukan langkah metode yang akan diterapkan, antara lain metode pendidikan masyarakat dan metode substitusi IPTEK. Metode pendidikan masyarakat yaitu memberikan pelatihan dan pendampingan dalam memanfaatkan aplikasi Quizizz sebagai alat evaluasi pembelajaran. Materi pelatihan yang diberikan terdiri dari empat, yakni pembuatan akun Quizizz, pembuatan soal di akun Quizizz, memberikan soal Quizizz ke siswa, dan cara siswa join kuis di Quizizz.

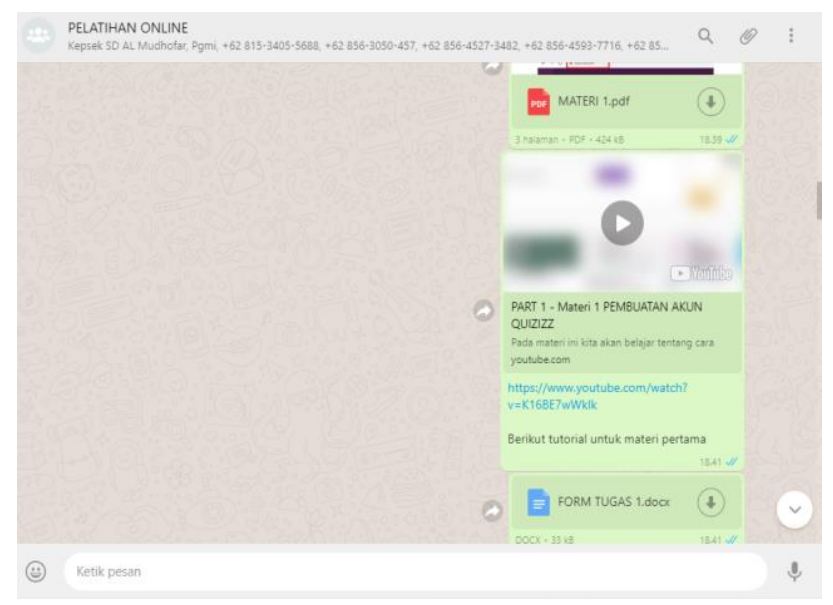

Gambar 1. Pembagian materi, link youtube, dan form tugas di group WhatsApp 


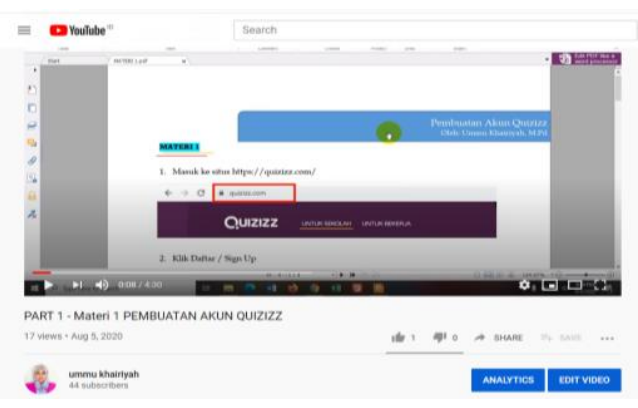

Gambar 2. Tutorial simulasi penggunaan aplikasi Quizizz menggunakan youtube

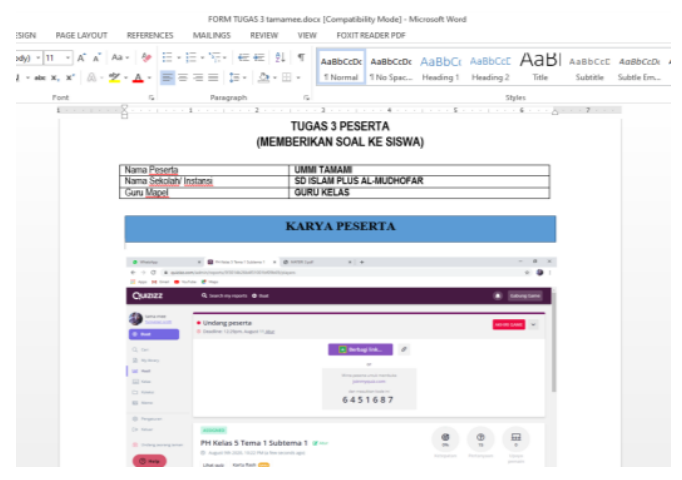

Gambar 3. Form tugas praktik yang dikerjakan oleh Guru

Tahap pelaksanaan program diawali dengan mengirimkan materi dan link Youtube di group pelatihan online (Gambar 1). Peserta menyimak simulasi penggunaan aplikasi Quizizz (Gambar 2) dari pemateri yang diikuti dengan praktik mandiri oleh masing-masing peserta dengan mengirimkan bukti screenshot di form tugas yang diberikan (Gambar 3).

Metode Substitusi IPTEK yaitu melakukan pendampingan sampai guru mampu mengaplikasikan penggunaan Quizizz kepada peserta didik dalam melakukan evaluasi pembelajaran. Tim terlibat dalam pengerjaan tes/ evaluasi seperti hal nya peserta didik dengan memasukkan kode evaluasi Quizizz guna mengetahui sejauh mana guru dapat menggunakan aplikasi Quizizz dan mengetahui antusias peserta didik mengikuti tes yang diberikan oleh guru.

\section{PEMBAHASAN \\ Perencanaan}

Pada tahap ini tim melakukan survey di 3 sekolah dasar yang berada di Desa Made kecamatan lamongan yakni SD Negeri Made 1, SD Islam Plus Al-Mudhofar, dan Ml Thoriqul ulum. Tim menemui masing-masing kepala sekolah untuk mendiskusikan waktu pelaksanaan dan materi yang akan dilatihkan selama proses pelatihan. Sebelumnya, guru mengisi kuisioner di google form untuk memetakan aplikasi apa saja yang digunakan selama pembelajaran daring. Dari hasil pengisian kuisioner diperoleh hasil sebanyak $81,25 \%$ guru menggunakan WA grup sebagai sarana pembelajaran daring, sisanya menggunakan aplikasi google classroom dan youtube.

Tabel 1. Jadwal kegiatan pelatihan

\begin{tabular}{|c|c|c|c|c|}
\hline No & Tanggal & Waktu & Kegiatan & Keterangan \\
\hline \multirow[t]{3}{*}{1} & 5 Agustus 2020 & $09.00 \mathrm{WIB}$ & $\begin{array}{l}\text { Share materi } 1 \text { (pembuatan akun } \\
\text { Quizizz) di Grup WA }\end{array}$ & Pemateri \\
\hline & & $11.00 \mathrm{WIB}$ & Diskusi dan Tanya Jawab & Pemateri dan peserta \\
\hline & & 13.00 WIB & Praktek Tugas Mandiri & Peserta \\
\hline \multirow[t]{3}{*}{2} & 6 Agustus 2020 & $09.00 \mathrm{WIB}$ & $\begin{array}{l}\text { Share materi } 2 \text { (pembuatan soal di } \\
\text { akun Quizizz) di Grup WA }\end{array}$ & Pemateri \\
\hline & & $11.00 \mathrm{WIB}$ & Diskusi dan Tanya Jawab & Pemateri dan peserta \\
\hline & & 13.00 WIB & Praktek Tugas Mandiri & Peserta \\
\hline \multirow[t]{3}{*}{3} & 7 Agustus 2020 & $09.00 \mathrm{WIB}$ & $\begin{array}{l}\text { Share materi } 3 \text { (membuat soal Quizizz } \\
\text { ke siswa) di Grup WA }\end{array}$ & Pemateri \\
\hline & & $11.00 \mathrm{WIB}$ & Diskusi dan Tanya Jawab & Pemateri dan peserta \\
\hline & & $13.00 \mathrm{WIB}$ & Praktek Tugas Mandiri & Peserta \\
\hline \multirow[t]{3}{*}{4} & 8 Agustus 2020 & $09.00 \mathrm{WIB}$ & $\begin{array}{l}\text { Share materi } 4 \text { (cara siswa join kuis di } \\
\text { Quizizz) di Grup WA }\end{array}$ & Pemateri \\
\hline & & $11.00 \mathrm{WIB}$ & Diskusi dan Tanya Jawab & Pemateri dan peserta \\
\hline & & $13.00 \mathrm{WIB}$ & $\begin{array}{l}\text { Praktek Tugas Mandiri (uji coba ke } \\
\text { siswa) }\end{array}$ & Peserta \\
\hline
\end{tabular}


Proses pelaksanaan evaluasi pembelajaran masih dilakukan secara konvensional dengan cara guru mengirim soal dalam bentuk foto dan dikirim di WA grup, kemudian siswa mengirim hasil jawaban dalam bentuk lembar kerja yang di foto juga. Pada awal rencana disusun jadwal kegiatan pelaksanaan pelatihan sebanyak 4 kali dimulai tanggal 5 Agustus sampai 8 Agustus 2020. Semua partisipan dalam pelatihan bersama-sama mengikuti kegiatan dalam waktu yang bersamaan (Tabel 1). Tim juga mempersiapkan materi berupa modul sederhana penggunaan aplikasi Quizizz beserta video tutorial yang di upload di youtube pemateri.

\section{Pelaksanaan}

Pelaksanaan kegiatan pelatihan pembuatan kuis interaktif dengan aplikasi Quizizz diawali dengan pemberian materi berupa modul sederhana (Gambar 4). Pada pertemuan pertama, peserta lebih dahulu diberikan materi tentang pengenalan aplikasi Quizizz sekaligus pembuatan akun Quizizz. Dikarenakan kondisi yang darurat, maka selain menggunakan modul sederhana, simulasi pembuatan akun Quizizz juga disampaikan secara virtual melalui youtube. Hal ini bertujuan supaya peserta dapat menyimak dan mengikuti langkah-langkah yang dilatihkan. Selama proses penyampaian materi, pemateri membuka kesempatan bertanya kepada peserta di WA grup jika ada langkahlangkah yang kurang jelas. Setelah materi disampaikan, pemateri masih membuka kesempatan kepada peserta untuk bertanya hal-hal yang belum dipahami.

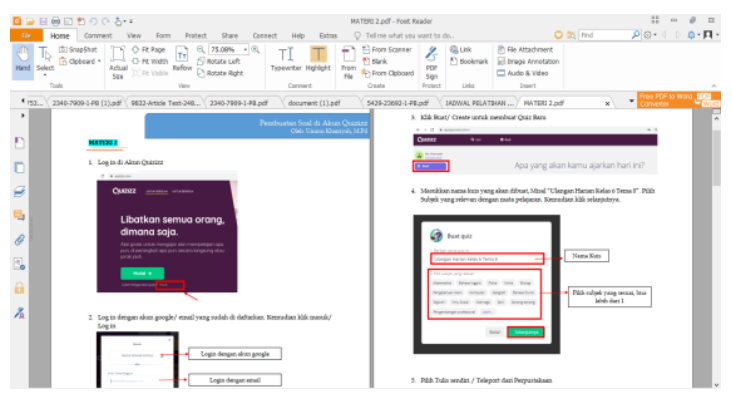

Gambar 4. Modul aplikasi Quizizz

Setelah dirasa peserta paham dengan materi yang telah disampaikan, peserta diminta untuk mengulang kembali langkah-langkah pembuatan akun quizizz, setelah peserta berhasil membuat akun, mereka diminta untuk screenshot hasil pembuatan akun di lembar form tugas yang diberikan. Hal tersebut dilakukan dengan tujuan mengetahui ketercapaian kompetensi peserta dalam mengikuti pelatihan online ini. Pertemuan kedua sampai keempat dilakukan hal yang sama seperti pada pertemuan pertama. Pada pertemuan terakhir, peserta diminta untuk mengujicobakan Quizizz yang telah dibuat selama pelatihan ke peserta didik pada kelas 4, 5 dan 6 (Gambar 5).

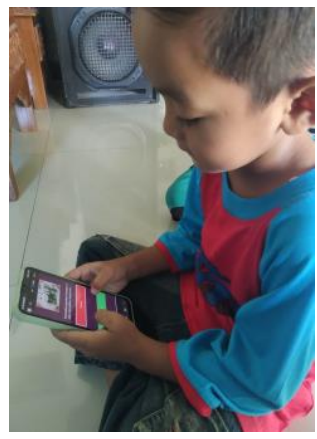

Gambar 5. Peserta didik melakukan evaluasi mata pelajaran seni budaya menggunakan aplikasi Quizizz yang dibuat oleh guru selama pelatihan

Dalam kegiatan pelaksanaan uji coba penggunaan Quizizz kepada peserta didik, tim ikut serta join dalam evaluasi pembelajaran menggunakan Quizizz. Pada ujicoba ini terlihat peserta pelatihan (guru) mampu mengoperasikan aplikasi Quizizz. Indikator keberhasilan masing-masing peserta adalah jika mampu membuat akun serta mengembangkan tes interaktif di Quizizz dan berhasil memposting kode tes kepada peserta didik. Setelah pendampingan berakhir, di dapat lebih dari $80 \%$ peserta mampu menggunakan aplikasi Quizizz (Tabel 2).

Dari 32 orang guru yang mengikuti pelatihan, 28 orang diantaranya telah mampu membuat tes interaktif dengan aplikasi Quizizz, sementara 4 orang guru yang lain masih menemui beberapa kendala sehingga dalam pembuatan tes interaktif dengan aplikasi Quizizz masih belum sempurna misalnya belum menentukan pilihan jawaban yang benar, belum menyertakan gambar pada soal dengan tingkat kognitf C4, dan lain-lain. Kendala tersebut bukan karena mereka belum paham dalam pembuatan tes di aplikasi Quizizz, tetapi karena faktor usia yang cenderung membuat mereka lupa pada setiap prosesnya. Hal tersebut bukan merupakan kendala teknis, sehingga dapat dikatakan tidak ditemukan masalah yang berarti dalam pelatihan ini. Pemanfaatan aplikasi Quizizz dalam evaluasi pembelajaran membuat peserta didik lebih antusias dan semangat mengerjakan, guru merasakan manfaatnya yaitu memudahkan dalam mengevaluasi siswa tanpa mengoreksi satu-satu hasil pengerjaan siswa dan merekap hasil pencapaian indikator peserta didik selama pembelajaran, 
Tabel 2. Tingkat Capaian Pelaksanaan Pelatihan

\begin{tabular}{|c|c|c|}
\hline No & Indikator ketercapaian & Tingkat capaian \\
\hline 1 & $\begin{array}{l}\text { Kehadiran } \\
\text { (> } 80 \% \text { peserta mengisi form kehadiran } \\
\text { selama } 4 \text { hari berturut-turut) }\end{array}$ & $\begin{array}{l}100 \% \text { dari } 32 \text { guru yang mengikuti pelatihan, } \\
\text { keseluruhan hadir selama kegiatan pelatihan } 4 \text { hari } \\
\text { berturut-turut }\end{array}$ \\
\hline 2 & $\begin{array}{l}\text { Respon Peserta } \\
\text { (respon peserta berkategori baik jika }>80 \% \\
\text { peserta bersikap antusias selama mengikuti } \\
\text { pelatihan) }\end{array}$ & $\begin{array}{l}100 \% \text { keseluruhan peserta antusias mengikuti pelatihan } \\
\text { dibuktikan dengan ketepatan waktu peserta dalam } \\
\text { mengumpulkan tugas }\end{array}$ \\
\hline 3 & $\begin{array}{l}\text { Pemahaman dan keterampilan } \\
\text { (tingkat pemahaman dan keterampilan } \\
\text { berkategori baik jika }>80 \% \text { peserta mampu } \\
\text { membuat dan mengembangkan tes } \\
\text { interaktif dengan aplikasi Quizizz) }\end{array}$ & $\begin{array}{l}87 \% \text { peserta pelatihan mampu mengembangkan tes } \\
\text { interaktif dengan aplikasi Quizizz. Sementara } 13 \% \text { yang } \\
\text { lain masih terdapat kekurangan dikarenakan faktor usia } \\
\text { dan belum lancar dalam penggunaan IT. }\end{array}$ \\
\hline 4 & $\begin{array}{l}\text { Penerapan aplikasi Quizizz } \\
\text { (>80\% peserta mampu mengujicobakan tes } \\
\text { interaktif yang dibuat kepada peserta didik } \\
\text { kelas atas) }\end{array}$ & $\begin{array}{l}81 \% \text { peserta mampu mengujicobakan aplikasi Quizizz } \\
\text { kepada peserta didik nya. Sementara } 19 \% \text { yang lain } \\
\text { belum mengujicobakan ke peserta didik, namun tes } \\
\text { yang dibuat di ujicobakan kepada peserta pelatihan } \\
\text { lain. }\end{array}$ \\
\hline
\end{tabular}

\section{KESIMPULAN}

Program pendampingan ini berdampak pada peningkatan kompetensi guru dalam membuat kuis atau evaluasi pembelajaran secara online dengan memanfaatkan aplikasi Quizizz. Adanya antusiasme yang tinggi dari peserta pelatihan dalam penggunaan Quizizz pada pembelajaran jarak jauh/ daring karena dapat membuat peserta didik bersemangat dalam menyelesaikan evaluasi pembelajaran yang diberikan oleh guru secara tepat waktu. Guru pun lebih mudah untuk melakukan penilaian. Dari perkembangan kasus Covid-19 yang belum mereda, dirasa program pelatihan penggunaan aplikasi berbasis virtual ini perlu dilakukan kepada kelompok guru-guru SD dari desa lain guna membantu guru dalam melakukan evaluasi pembelajaran selama pembelajaran daring/ online

\section{UCAPAN TERIMA KASIH}

Penulis mengucapkan terima kasih kepada kelompok Guru Sekolah Dasar di Desa Made Kecamatan Lamongan yang dengan semangat mengikuti pelatihan hingga selesai. Penulis juga mengucapkan terima kasih kepada Litbang Pemas Universitas Islam Lamongan yang telah membantu pendanaan untuk pelaksanaan kegiatan pelatihan ini. Ucapan terimakasih juga disampaikan kepada mahasiswa KKN kelompok 34 yang telah membantu dalam melaksanakan kegiatan pelatihan ini.

\section{DAFTAR PUSTAKA}

Arifin, Z. (2016). Evaluasi pembelajaran. Jakarta: PT.Remaja Rosda Karya. https://adoc.pub/evaluasipembelajaran-drs-zainal-arifin-mpd.html

Arizona, K., Abidin, Z., \& Rumansyah, R. (2020). Pembelajaran online berbasis proyek salah satu solusi kegiatan mengajar di tengah pandemic covid-19. Jurnal Ilmiah Profesi Pendidikan, 5(1), 64-70. https://doi.org/10.29303/jipp.v5i1.111

Fuady, M. J. (2017). Pengembangan aplikasi evaluasi pembelajaran online untuk pendidikan jarak jauh. Tekno, 26(2), 148-154. http://journal.um.ac.id/index.php/tekno/article/view 18281

Hartley, D. E. (2001). Selling E-Learning. American Society for Training \& Development. https://books.google.co.id/books?id=jcnh8Vcw0-IC

labal, W. M. G., Fadhilah, R., \& Hadiarti, D. (2018). Pengembangan Alat Evaluasi Berbasis Wondershare Quiz Creator Pada Materi Koloid Kelas XI Di SMA Koperasi Pontianak. AR-RAZI Jurnal IImiah, 6(1), 11-19. https://doi.org/10.29406/arz.v6i1.937

Mardapi, D. (2012). Pengukuran penilaian dan evaluasi pendidikan. Yogyakarta: Nuha Medika.

Nurzannah, N., \& Setiawan, H. R. (2020). Program Kemitraan Masyarakat Di Tengah Pandemi Covid-19 Bagi Guru SD (Pembuatan Media Evaluasi Pembelajaran Online). JCES (Journal of Character Education Society), 3(2), 299-310. http://journal.ummat.ac.id/index.php/JCES/article/vi ew/2340

Pratiwi, V. (2017). Pengembangan Alat Evaluasi Pembelajaran Berbasis ICT Menggunakan Wondershare Quiz Creator Pada Materi Penyusutan Aset Tetap. Prosiding Seminar Pendidikan Ekonomi Dan Bisnis, 3(1), 1-7. https://jurnal.fkip.uns.ac.id/index.php/snpe/article/vi ew/10698

Purba, L. S. L. (2019). Peningkatan Konsentrasi Belajar Mahasiswa Melalui Pemanfaatan Evaluasi Pembelajaran Quizizz Pada Mata Kuliah Kimia Fisika I. Jurnal Dinamika Pendidikan, 12(1), 29-39. https://doi.org/10.33541/jdp.v12i 1.1028

Rolisca, C. R. U., \& Achadiyah, B. N. (2014). Pengembangan Media Evaluasi Pembelajaran dalam Bentuk Online Berbasis ELearning Menggunakan Software 
Wondershare Quiz Creator dalam Mata Pelajaran Akutansi di SMA Brawijaya Smart School (BSS). Jurnal Pendidikan Akuntansi Indonesia, 12(2), 41-48. https://doi.org/10.21831/jpai.v12i2.2706

Safi'i, I. (2018). Nilai-nilai pendidikan karakter dalam alat evaluasi bahasa Indonesia. Jurnal Pendidikan Karakter, 8(1), 74-83. https://journal.uny.ac.id/index.php/jpka/article/view 121676

Sari, D. D., \& Rini, T. P. W. (2020). Bimbingan Teknis Pembelajaran Daring Menggunakan Aplikasi Quizizz Bagi Guru Sekolah Dasar Pada Masa Pandemi Covid19. Jurnal Pendidikan Dan Pengabdian Masyarakat, 3(4), 213-217. http://www.jurnalfkip.unram.ac.id/index.php/JPPM/ article/view/2204
Suryana, Y., \& Irawantoro, N. (2016). Kompetensi Pedagogik untuk Peningkatan dan Penilaian Kinerja Guru dalam Rangka Implementasi Kurikulum Nasional. Surabaya: Genta Group Production.

Suyasa, P. W. A., Divayana, D. G. H., Putrama, I. M., \& Damayanthi, L. P. E. (2019). Pelatihan Pembuatan Tes Interaktif Dengan Aplikasi Quizizz Bagi Paea Guru Di SMPN 2 Kediri. Seminar Nasional Pengabdian Kepada Masyarakat, 4 , 24-29. https://eproceeding.undiksha.ac.id/index.php/sena dimas/article/view/1704

Yan mei, S., Yan Ju, S., \& Adam, Z. (2018). Implementing Quizizz as Game Based Learning in the Arabic Classroom. European Journal of Social Science Education and Research, 5(1), 194-198. https://doi.org/10.2478/ejser-2018-0022 